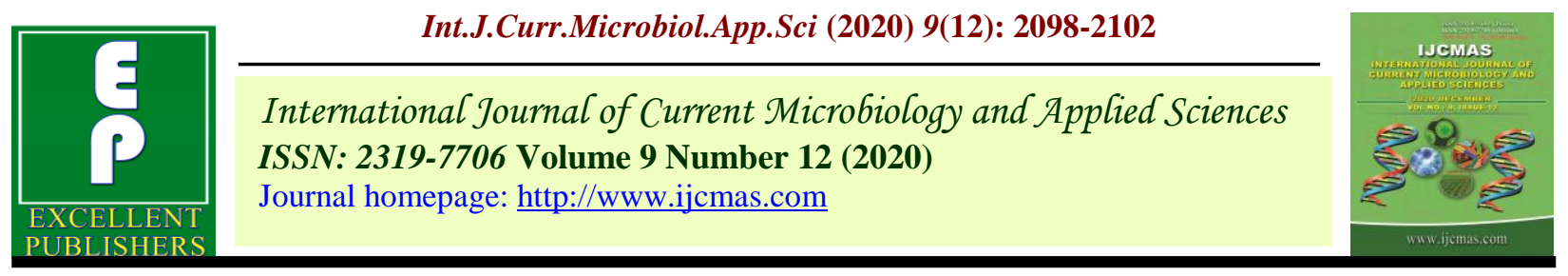

Original Research Article

https://doi.org/10.20546/ijcmas.2020.912.246

\title{
Resource Use Efficiency in Bottle Gourd in Meerut District of Western Uttar Pradesh, India
}

\author{
Krishna Kant*, Praveen K. Sahu and J. P. Singh \\ Department of Agricultural Economics NDUAT Kumarganj Ayodhya, India \\ *Corresponding author
}

\begin{tabular}{l} 
K e y w o r d s \\
$\begin{array}{l}\text { Resource use } \\
\text { efficiency. Return } \\
\text { to scale. Marginal } \\
\text { value productivity }\end{array}$ \\
\hline Article Info \\
$\begin{array}{l}\text { Accepted: } \\
\text { 14 November } 2020 \\
\text { Available Online: } \\
\text { 10 December } 2020\end{array}$ \\
\hline
\end{tabular}

\section{A B S T R A C T}

Vegetable cultivation plays an important role in the agricultural economy of India. Small and marginal farmers of India grow vegetable for generating income and increasing nutrient in the diet of people. But limited research was done on profitability and resource use efficiency of bottle gourd which are the crucial vegetable crops grown by farmers in Meerut. On the basis of primary data to know resource use efficiency of bottle gourd cultivation. The purposive sampling was used to select districts and villages on the basis of highest area under these crops random sampling technique was used to select the 100 farmers and categorized under marginal small and medium farmers. Study concluded coefficient of multiple determinations $\left(\mathrm{R}^{2}\right)$ human labour, seed, manure and fertilizers and irrigation together contributed $88.2450,83.4458$ and 85.4872 , per cent, that efficient use of resources. human labour and plant protection were statistically significant at 1 per cent level of significance Returns to scale on marginal, small and medium farms were analysed and found to be less than unity. Marginal value productivity in case of human labour on all three categories was found more than unity.

\section{Introduction}

India is the second largest producer of vegetables in the world next to China with area and production of 162.90 million hectare and 268.285 million tonnes and Uttar Pradesh has an important place in area and production with $14.52 \mathrm{~m}$ ha and 427.81 thousand tonnes in bottle guard (year 2017-18) and also Meerut district occupy a crucial place in bottle guard area and production with $.49 \mathrm{~m}$ ha and 14.21 thousand tonnes (year 2016-17) (Anonymous, 2018). The vegetable cultivation is preponderance of small and marginal farmers and also family labours were done all the operation of vegetable cultivation. Vegetables are the most important component of a balanced diet and provide health security to people by supplying nutrition through it. Now-a-days consumer's preferences have also shifted away from cereals and moved towards vegetables for balanced diet (Mittal, 2006). While, vegetable 
cultivation is facing the challenge of profitability and economical use of resources. Therefore, an analysis at the farm level is desirable to get a clear understanding of the existence of gap between actual and potential output of agriculture crop in different regions. It is stated in the literature that the ratio between the actual and potential output is the measure of resource use efficiency of a farm/farmer and the various socio-economic characteristics of the farmers and other geographical (ecological) factors determine the variations in the efficiency level of farmers (Kalirajan and Shand, 1994)

\section{Materials and Methods}

The district Meerut was selected purposively to avoid the operational inconvenience of the investigator. Out of twelve blocks of selected district, one block namely Kharkoda having highest area under vegetables crop was selected purposively. A list of all the villages falling under selected block was prepared and arranged in ascending order according to area covered by vegetables crop therefore; five villages were selected randomly from the list. A separate list of vegetables growers of selected five villages was prepared along with their size of holdings. Thus, the farm holding categorized into three size groups i.e. (1) Marginal (below 1.0 hectare), (2) Small (1.0 to 2.0 ha.) and (3) Medium (2.0 to 4.0 ha.) from this list a sample of hundred respondents were selected following the proportionate random sampling technique.

\section{Statistical tool}

The effect of various independent variables on the dependent variables, various forms of production function were explored. However, Cobb-Douglas production function, elasticity of production and return to scale, was found to be best fit for the analysis of data.
The mathematical form of Cobb-Douglas function (power function) is as follows:

$\mathrm{Y}=\mathrm{ax}_{1}{ }^{\mathrm{b}_{1}} \cdot \mathrm{x}_{2} \mathrm{~b}_{2} \ldots \ldots \ldots \ldots \ldots \ldots \ldots \mathrm{Xn}^{\mathrm{bn}}$

Where,

$\mathrm{Y}=$ Dependent variable (output value in rupees/hectare)

$\mathrm{X}_{1}=\mathrm{i}^{\text {th }}$ independent variable (input value rupees/hectare)

$\mathrm{a}=$ Constant

$\mathrm{b}_{1}=$ Production elasticity with respect to $\mathrm{X}_{\mathrm{i}}$ 's

The value of the constant (a) and coefficient (bi) in respect of independent variable in the function have been estimated by using the method of least square. The Cobb-Douglas production function in log form is as follows:

$\log Y=\log a+b_{1} \log X_{1}+b_{2} \log X_{2}+b_{3} \log$ $\mathrm{X}_{3}+\mathrm{b}_{4} \log \mathrm{X}_{4}+\ldots \ldots+\mathrm{u} \log \mathrm{e}$

Where,

$\mathrm{Y}=\quad$ Value of gross returns of crops

(Rs./ha)

$\mathrm{X}_{1}=$ Expenditure on human labour (Rs./ha)

$\mathrm{X}_{2}=$ Expenditure on seed (Rs./ha)

$\mathrm{X}_{3}=$ Expenditure on manures and fertilizers (Rs./ha)

$\mathrm{X}_{4}=$ Expenditure on plant protection (Rs./ha)

$\mathrm{a}=$ Intercept

$b_{i}:(j=1,2 \ldots \ldots .4)$ are the elasticity coefficient of the $j^{\text {th }}$

The marginal value of product Inputs were estimated by following formula:

(MVP) $X_{j}=b_{j} \frac{\bar{Y}}{\bar{X}_{j}}$

Where,

$\mathrm{b}_{\mathrm{j}}=$ Production elasticity with respect to $X_{j}$ 
$\mathrm{Y}=$ Geometric mean of the dependent variable $\mathrm{Y}$

$\mathrm{X}_{\mathrm{j}}=$ Geometric mean value of $\mathrm{X}_{\mathrm{j}}$

MVP $=$ Marginal value product of $\mathrm{j}^{\text {th }}$ input, significance test of the simple regression coefficient.

Having estimates of the elasticity coefficients, it is desirable to ascertain the reliability of these estimates. The most commonly used ' $t$ ' test was applied to ascertain whether the sample production elasticity coefficient; bj is significantly different from zero or not at some specified probability level.

' $t$ ' cal $=b_{j} /$ standard error of $b_{j}$

If cal. ' $t$ 'is greater than table value of $t$ distribution at (n-k-1) degree of freedom and specified probability level of significance, $b_{j}$ is said to be statistically significant from zero ( $\mathrm{K}$ is number of independent variable and $\mathrm{n}$ is sample size).

\section{Results and Discussion}

Resource Use Efficiency means how efficiently the farmer can use his resources in production process. It is very important because our resource is very limited. For calculating resource use efficiency, we consider four factors namely Human labour, seed, manure fertilizer and plant protection.

Coefficient of multiple determinations $\left(\mathrm{R}^{2}\right)$ on marginal, small and medium size group of farms accounted for $0.882450,0.834458$ and 0.854872 , respectively and indicating that all the explanatory variable viz., human labour, seed, manure and fertilizers and plant protection together contributed 88.2450, 83.4458 and 85.4872 , per cent, respectively.

It is observed from that on marginal farms, the elasticity of production with respect to human labour and plant protection were statistically significant at 1 per cent level of significance and seed and manure \& fertilizer were found significant at 5 per cent level of significance that these input factors contributed to the output significantly. In case of small farms, elasticity of production with respect to human labour and seed were found significant at 1 per cent level of significance, respectively. In case of medium farms, elasticity of production with respect to human labour, and seed were found significant at 1 per cent and 5 per cent level of significance, respectively, Rest factors of production included in production process were found statistically non-significant. It can be inferred that there was no further scope for application of these input in production of bottle gourd.

Returns to scale on marginal, small and medium farms were analysed and observed to be 0.95527, 0.89268 and 0.91705, respectively, which was found to be less than unity. It is therefore, inferred that increasing all factors by one per cent simultaneously results increase of the returns by less than 1 per cent on each farm situation. Sum of Elasticity's an increasing return to scale.

marginal value productivities are positive and more than unity in case of human labour, manure \& fertilizer and seed (excluding medium farms) and less than unity in plant protection in respect of marginal, small and excluding medium farms.

In case of more than unity (human labour, manure \& fertilizer and seed excluding medium farm) as indicates scope for increasing the expenditure on this input variable. In case of human labour on all three category and seeds (marginal and small farms) was found more than unity which indicated excess investment on this variable hence, there are need to decrease it, for increasing profitability of farms (Table 1). 
Table.1 Elasticity coefficient of the production function for bottle gourd

\begin{tabular}{|c|c|c|c|c|c|c|c|c|c|c|}
\hline \multirow{2}{*}{$\begin{array}{l}\text { Size group } \\
\text { of farms }\end{array}$} & & \multicolumn{3}{|c|}{ Production Elasticity's } & \multirow{2}{*}{$\begin{array}{c}\text { Sum of } \\
\text { elasticity's }\end{array}$} & \multirow[t]{2}{*}{$\mathbf{R}^{2}$} & \multicolumn{4}{|c|}{ Marginal value product of inputs /factors } \\
\hline & $\begin{array}{c}\text { Human } \\
\text { Labour } \\
\left(\mathbf{X}_{1}\right)\end{array}$ & $\begin{array}{r}\text { Seed } \\
\left(\mathbf{X}_{2}\right)\end{array}$ & $\begin{array}{l}\text { Manure\& } \\
\text { fertilizers } \\
\quad\left(\mathbf{X}_{3}\right)\end{array}$ & $\begin{array}{c}\text { Plant } \\
\text { protection } \\
\left(\mathbf{X}_{4}\right)\end{array}$ & & & $\begin{array}{c}\text { Human } \\
\text { Labour } \\
\left(\mathbf{X}_{1}\right)\end{array}$ & $\begin{array}{r}\text { Seed } \\
\left(\mathbf{X}_{2}\right)\end{array}$ & $\begin{array}{c}\text { Manure } \\
\& \\
\text { fertilizers } \\
\left(\mathbf{X}_{3}\right)\end{array}$ & $\begin{array}{c}\text { Plant } \\
\text { protection } \\
\left(\mathbf{X}_{4}\right)\end{array}$ \\
\hline $\begin{array}{c}\text { Marginal } \\
\text { below } 1 \text { ha }\end{array}$ & $\begin{array}{c}0.19690 * * \\
(0.0 .08492)\end{array}$ & $\begin{array}{l}0.093728^{*} \\
(0.125497)\end{array}$ & $\begin{array}{l}0.049551 * \\
(0.022014)\end{array}$ & $\begin{array}{c}0.067457 * * \\
(0.017124)\end{array}$ & 0.95527 & 0.882450 & 3.98 & 1.24 & 1.34 & 0.67 \\
\hline $\begin{array}{c}\text { Small 1-2 } \\
\text { ha }\end{array}$ & $\begin{array}{l}0.44875 * * \\
(0.082487)\end{array}$ & $\begin{array}{c}0.224838^{*} \\
* \\
(0.057812 \\
4)\end{array}$ & $\begin{array}{c}0.062145 \\
(0.089554)\end{array}$ & $\begin{array}{c}0.161248 \\
(0.109124)\end{array}$ & 0.89268 & 0.834458 & 3.87 & 1.14 & 1.58 & 0.84 \\
\hline $\begin{array}{c}\text { Medium } \\
\text { 2-4 ha }\end{array}$ & $\begin{array}{c}0.43754 * * \\
(0.1962104)\end{array}$ & $\begin{array}{l}0.220484^{*} \\
(0.139412)\end{array}$ & $\begin{array}{c}0.078221 \\
(0.583197)\end{array}$ & $\begin{array}{c}0.166168 \\
(0.127158)\end{array}$ & 0.91705 & 0.854872 & 3.24 & 0.78 & 1.12 & 1.25 \\
\hline
\end{tabular}

Figures in parentheses show standard error of respective variable) $* * 1 \%$ level of significance.

$* 5 \%$ level of significance 
Study concluded that farmers of medium category of land holding have good economic conditions due to better management practices and efficient use of resources. So, trainings should organize to impart technological know-how at door step through extension workers and agricultural research stations. It would be helpful for improvement of scientific knowledge of farmers for bottle gourd cultivation practices and efficient use of productive resources.

\section{Acknowledgement}

The authors are grateful to Acharya Narendra Deva University of Agricultural \& Technology Kumarganj Ayodhya for providing the financial assistance and successful completion of Ph D work

\section{References}

Anim, F. D. K.; Thaba, K. and Tshikororo, M. (2015) Resource Use Efficiency in Vegetable Production under Irrigation: The Case of Marutle Agricultural Cooperative in the Limpopo Province of South Africa, J Hum Ecol, 50(1): 11-17.

Dumsile D. F. and Kongolo, M. (2014). Resource Use Efficiency in Organic Vegetable Production: A Case Study of Manzini Region, Swaziland, Journal of Agricultural Studies ISSN 2166-0379 2014, Vol. 2, No. 2.
Etim, N. A. A. and Udoh, E. J. (2014) "Identifying sources of efficiency among resource poor indigenous vegetable farmers in Uyo, Nigeria." International Journal of Food and Agricultural Economics; 2014. 2(1):33-39. 26 ref. [Journal article] AN: 20143303613.

Goni, M., Umar, A.S.S. and Usman, S. (2013) Analysis of Resource-Use Efficiency in Dry Season Vegetable Production in Jere, Borno State, Nigeria, Journal of Biology, Agriculture and Healthcare, Vol.3, No.19, 2013.

Horticultural Statistics at a Glance, 2018.

Kalirajan K P and K T Shand (1994) Economics in Disequilibrium: An Approach from the frontier. Macmillan India Ltd, New Delhi.

Mittal S. (2006). Structural shift in demand for food: Projections for 2020. Working Paper No. 184. New Delhi. Indian Council for Research on International Economic Relations (ICRIER).

Okon, U.E. and Enete A.A. (2009) Resource Use Efficiency among Urban Vegetable Farmers in Akwa Ibom State, Nigeria, TROPICULTURA, 2009, 27, 4, 211-217about watershed development programme". Karnataka Journal of Agricultural Science. 19(4): 867-871.

\section{How to cite this article:}

Krishna Kant, Praveen K. Sahu and Singh, J. P. 2020. Resource Use Efficiency in Bottle Gourd in Meerut District of Western Uttar Pradesh, India. Int.J.Curr.Microbiol.App.Sci. 9(12): 20982102. doi: https://doi.org/10.20546/ijcmas.2020.912.246 